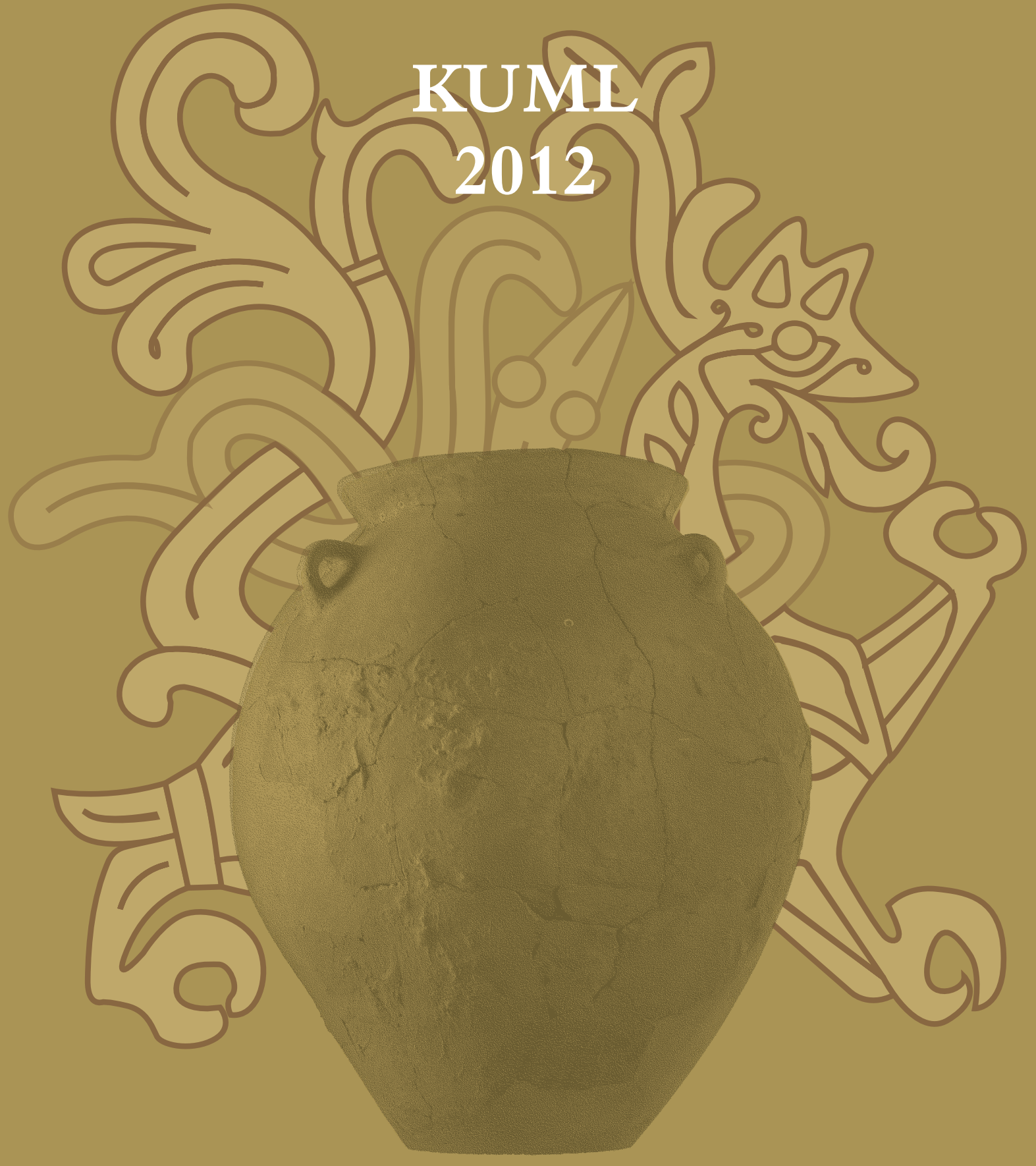




\section{KUML 2012}

Årbog for Jysk Arkæologisk Selskab

With summaries in English

I kommission hos Aarhus Universitetsforlag 


\title{
Ringbrynje fra Aarhus
}

\author{
Af LEA HILLEBRENNER PIND
}

Når man nævner ordet "rustning", så får de fleste nok associationer til middelalderen og ser for sig en ridder i pladerustning til hest, tordnende i strakt karriere og med sænket lanse mod en tilsvarende udstyret modstander. Af rustningens næsten 2000-årige historie er det dog kun de sidste ca. 400 år, at pladerustningen dominerede. Indtil da havde rustninger af ringbrynje været fremherskende på slagmarken. Ringbrynje er lavet af massevis af små jern- eller messingringe sat minutiøst sammen, så det næsten fungerer som strik af garn, og en sådan rustning er derfor fleksibel og forbavsende beskyttende, endskønt den - om man så må sige - mest består af huller med lidt jern omkring.

På trods af det lange tidsrum rustningsdele af ringbrynje har været i brug, kender vi dem næsten ikke, hverken som genstande gemt i våbenkamre eller som fund fra arkæologiske udgravninger. Når de endelig dukker op i forbindelse med arkæologiske udgravninger, måske med 10 eller 20 års mellemrum, kan de være vanskelige at identificere og typologisere, fordi man som regel blot står med en lille forrustet jernklump. Det er først, når det er større stykker, eventuelt en hel hauberk (en brynjeskjorte) eller andre specielle genstande, at man nemt kan se, hvad der er blevet fundet. Derfor er langt den meste litteratur om rustninger oftest fokuseret på genstande bevaret i samlinger, men med blot en smule basal viden kan man også få udvidet sit kendskab ved at inddrage de rustningsdele, som hidrører fra arkæologiske udgravninger.

I det følgende vil jeg kort gennemgå ringbrynjens kulturhistorie og redegøre for, hvordan den fremstilles, og dernæst præsentere en række fund af ringbrynjestykker fra Aarhus.

\section{Ringbrynjens oprindelse}

Ordet ringbrynje vil i det følgende udelukkende blive brugt om konstruktionsmetoden, altså selve samlingen eller vævningen af jernringene. Grunden hertil er, at den rustningsdel, langt de fleste forstår som "en ringbrynje", altså kropsbeskyttelse til torso og arme, i middelalderlige inventarielister, levnedsbeskrivelser og skønlitterære værker betegnes som en hauberk (fig. 1). 
Fig. 1. Hauberk fremstillet i Iserlohn, ca. 1430. - Board of Trustees of the Armouries.

Hauberk made in Iserlohn, c. 1430.

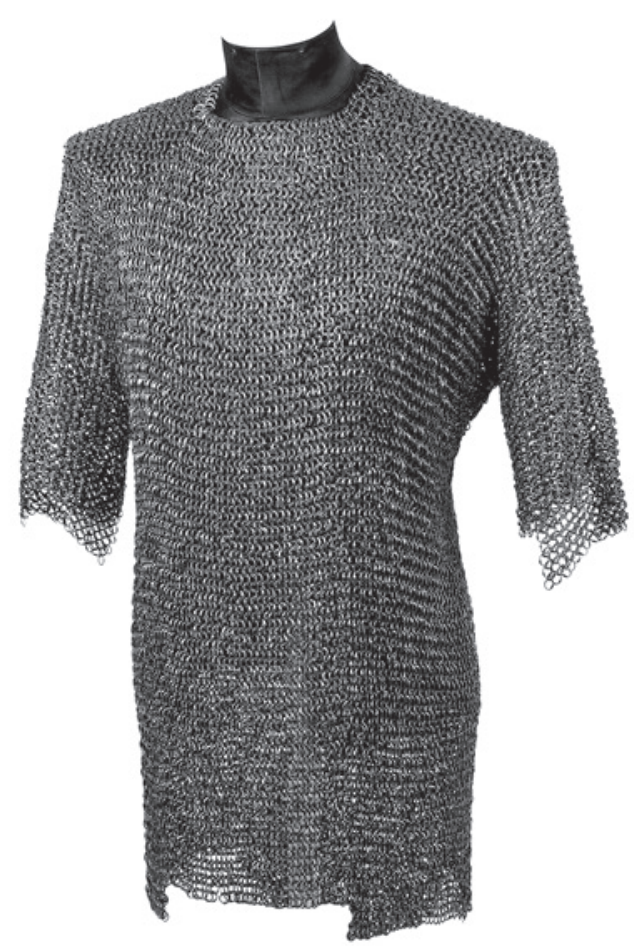

Man støder i kilderne også på navne som haubergeon, haubergnon, birnie og byrnie, og mange gange kaldes den på dansk en panser- eller ringskjorte, måske med kraftig skelen til det engelske navn "a mail shirt".

Ringbrynje introduceres senest i det 3. århundrede f.Kr. i Europa. På den tid hentede Romerrigets hær galliske smede til at producere ringbrynje til rustninger for sig. De romerske historieskrivere mener, at gallerne opfandt ringbrynje, men det er dog ikke i gallernes Frankrig, det ældste hauberkfund i Europa er gjort. Det er derimod i det nuværende Rumænien i en ryttergrav fra det 3. århundrede f.Kr. ${ }^{2}$ Hvem der opfandt ringbrynje, og hvorhenne er stadig uafklaret, men i Mellemøsten er der fundet stykker af ringbrynje i nomadegrave dateret til det 5 . århundrede f.Kr. Der er dog rejst tvivl om, hvorvidt det er produceret lokalt eller bragt dertil. ${ }^{3}$

I Danmark har vi en lang række ringbrynjefund fra romersk jernalder (0400 e.Kr.). I bl.a. Hedegård, Brokær, Thorsbjerg og Viemose er der fundet både større stykker af ringbrynje og hele hauberker. ${ }^{4}$ De fem fund, der vil blive beskrevet i det følgende, er fra vikingetid og middelalder, spændende over tidsrummet fra slutningen af 900-tallet til slutningen af 1500-tallet og er alle fundet i Aarhus. I to af tilfældene kan det dog ikke med sikkerhed afgøres, hvad de oprindeligt har været brugt til. 
En gravfunden hauberk fra Hedegård nær Skjern er dateret til tiden omkring vor tidsregning og viser sig ved analyser af slaggeinklusionerne i jernet sandsynligvis at være fremstillet $\mathrm{i}$ det nuværende nordtyske eller polske område, selv om den er udformet helt efter romerske standarder. ${ }^{5}$

Da Vestromerriget brød sammen i 400 -tallet, forsvandt samtidig den mangfoldige rustningstradition, romerne havde opbygget, og ringbrynje blev nu den dominerende konstruktionsmetode til rustninger i Europa de næste ca. 1000 år. Mens den romerske hær havde sørget for, at alle soldater var passende udrustet, blev rustningen nu et status- og rigdomssymbol i århundrederne efter Romerrigets sammenbrud. ${ }^{6}$

\section{Rustningernes udformning og brug}

Hauberken, som skulle beskytte selve kroppen, er oftest hoftelang med albuelange ærmer og har nogle gange en slids foran i halsudskæringen (fig. 1). Den udformning af hauberken ses fra de allerældste fund og langt op i tiden, endda længere end den generelle brug af rustninger i krigsøjemed, men variationer kendes specielt inden for Romerrigets grænser? ${ }^{7}$

Det var først i 1000-tallet, der skete en forandring i hauberken, idet den nu får hellange ærmer for at beskytte underarmene, der indtil da var blevet beskyttet af løse stykker ringbrynje bundet om armene. ${ }^{8}$ I slutningen af 1100 -tallet forlænges ærmerne igen, så det yderste stykke kan laves om til en flap eller luffe til at beskytte hånden. En flap holdes på plads med en rem eller strop om hånden, og en luffe lukkes af $\mathrm{i}$ håndfladen med et stykke læder med en slids i, gerne på langs, så det er muligt både at få et ordentligt greb og at få hænderne fri uden at skulle have hele rustningen af. 9

I slutningen af 1200-tallet begynder man at eksperimentere med at lave rustninger af små stykker jernplade, og i løbet af 1300-tallet bliver rustningsdele af ringbrynje næsten udkonkurreret. Pladerustningen er opbygget af jernplader, der er klippet til, hamret i facon og derefter sat sammen med nitter og læderremme. Det er svært at lave en pladerustning, der er lige så smidig som en rustning af ringbrynje, så det tog Europas rustningssmede næsten 200 års eksperimenter at nå frem til et tilfredsstillende resultat. Det er netop, fordi rustningsdele af ringbrynje er smidige, at de stadig bliver brugt i 1300-, 1400og 1500-tallet, specielt til beskyttelse af vanskelige steder, som bag- og indersider af led og åbninger mellem forskellige plader. ${ }^{10}$

I løbet af 1500-tallet begynder rustningen lige så stille at glide ud af brug. Den er blevet utilstrækkelig over for de nye typer krudtvåben og den ændrede krigsførelse, disse førte med sig, og til slut, i løbet af 1600-tallet, ville de me- 
Fig. 2. Brigantine fra slutningen af 1400-tallet med ringbrynjexrmer. Den er sat sammen med en hjelm, kaldet en "Salade", en lille ringbrynjekrave og en hellebard, en såkaldt "Bill". Billedet er beskåret, så man ikke kan se hele opstillingen. Board of Trustees of the Armouries.

Brigandine from the late 15 th century with ring mail sleeves. Here exhibited with a helmet called a "Salade", a small ring mail collar and a halberd, a so-called "bill". The picture has been cropped so it is not possible to see the entire exhibit.

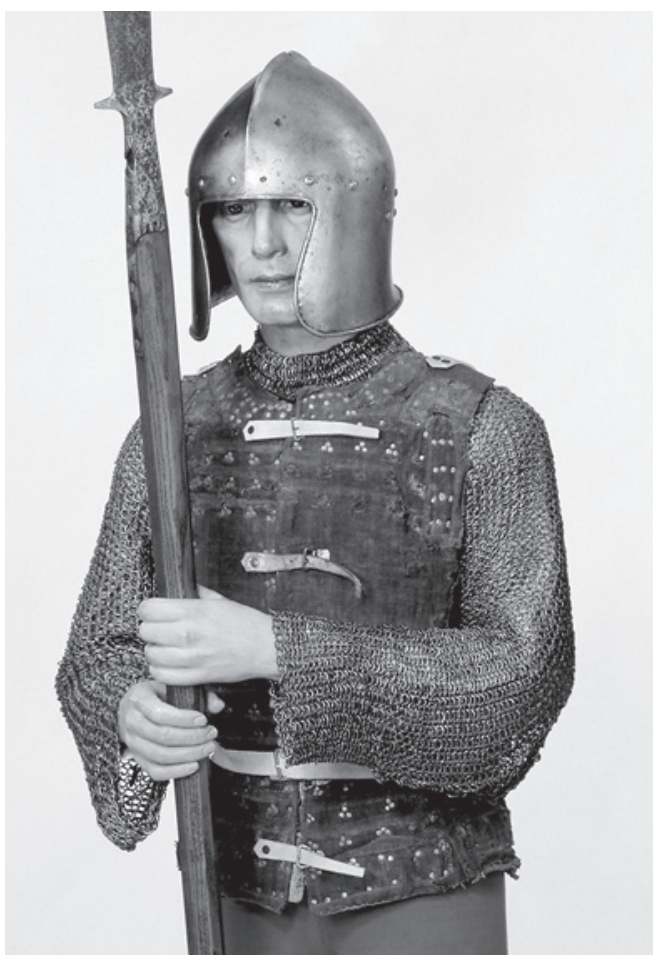

nige fodsoldater hellere have "en potte vin til beskyttelse", fordi rustningerne var for tunge og ubekvemme i forhold til, hvad de beskyttede. ${ }^{11}$

Der blev stadig lavet kvalitets- og pragtrustninger i 1500-tallet, men langt den største produktion gjaldt nu rustninger af lavere kvalitet, der helst også skulle være hurtige og billige at lave. Regnskaber fra både rustningsproducenter og tøjhuse fortæller, at en populær løsning på det problem er en brigantine, en stof- eller læderjakke, nærmere en vest, med hundredvis af små, taglagte jernplader nittet på indersiden, i nogle tilfælde fuldendt med ærmer af ringbrynje (fig. 2). Den kendes med sikkerhed fra begyndelsen af 1400-tallet, men vinder først rigtig popularitet blandt fodsoldater og prisbevidste borgere i den anden halvdel af 1500-tallet. ${ }^{12}$ Brigantinen havde gerne en stærk farve på ydersiden, rød og blå var populære, og med grå, metalfarvede ærmer kommer den til at ligne det sene 1500-tals finere herrebeklædning: En "doublet”, kombinationen af en langærmet hoftelang jakke med en ærmeløs vest i kontrastfarve båret udenpå. ${ }^{13}$

En rustning uanset konstruktion eller udseende er altid lavet mindst "et nummer for stor" til personen, der skal bære den, for herved at give passende bevægelsesfrihed. Men ligegyldigt hvor godt den enkelte rustning end er ud- 
ført, og hvor minutiøst den er tilpasset den enkelte person, bæres der altid en beskyttende, vatteret underklædning fremstillet af flere lag læder eller stof quiltet sammen med fæhår eller strå imellem. I forbindelse med pladerustninger er det for at undgå, at pladekanterne gnaver og trykker og for at holde rustningen på plads på kroppen, men til en rustning af ringbrynje er underklædningen faktisk en aktiv del af rustningens beskyttende effekt. ${ }^{14}$

Ringbrynje er nemlig mere sejt end solidt. Det beskytter bæreren mod kødsår, men det kan ikke i sig selv absorbere kraften i et hug, fordi det er smidigt. Det er den tykke underklædning, der optager og fordeler trykket af slaget, så man måske kan nøjes med store blå mærker eller mindre knoglebrud frem for store, blødende kødsår. Dette afspejles også i våbnene brugt mod ringbrynje- og pladerustninger. Det er først med introduktionen af pladerustningen i 1300-tallet, at der findes en udpræget od på de samtidige sværd. Ældre sværd, fra den romerske Gladius til vikingetidens pragtsværd, har blot en flad, kort od. ${ }^{15}$

I længden kunne rustningshåndværket ikke hamle op med våbenteknologiens rivende udvikling, og kunsten at lave både plade- og ringbrynjerustninger forsvandt stort set fra Europa i løbet af 1600- og 1700-tallet, mens man i Mellemøsten og i Afrika blev ved med at producere hauberker af ringe kvalitet til en mere ceremoniel rolle som status- og rigdomssymbol for storhøvdinge uden egentlig forbindelse til deres oprindelige funktion som rustning; en praksis, der først forsvandt i løbet af 1900-tallet. ${ }^{16}$

\section{Fremstilling af ringbrynje}

Hvordan man fremstiller ringbrynje kan egentlig forklares ganske enkelt. Man forbinder fire ringe med en femte, og så fortsætter man med at forbinde kvintetterne med flere ringe, indtil stykket har den ønskede størrelse (fig. 3). Men som med andre enkle ting, er det en del sværere, end det lyder. Ringbrynje er nemlig mest smidig i én retning. ${ }^{17}$

Når man samler et stykke ringbrynje korrekt, dannes et mønster i "vævningen”. På den ene led ligger ringene i lange baner som faldne dominobrikker, der vender modsat af banen over og under. På den anden led danner ringene lange bølger eller S'er, der sidder sammen.

Ringbrynje er mest smidigt langs "domino"-banerne, fordi ringene her ligger parat på skrå og på den rette led til at glide ind over og under hinanden. På den anden led mødes ringene kant mod kant og kan ikke så nemt pakkes mere sammen (fig. 4).

Den smidige retning skal løbe rundt om kroppen på en hauberk, så det er nemmere at få den af og på. Da ærmerne laves ud i et med resten af hauberken, 
Fig. 3. Princippet i fremstilling af ringbrynje: fire ringe forbundet med en femte. Ganske enkelt, i det mindste i teorien. - Efter Burgess 1953b. Cambridge University Press.

Principle of manufacture of chain mail: four rings are joined together with a fifth. Very simple, at least in theory.

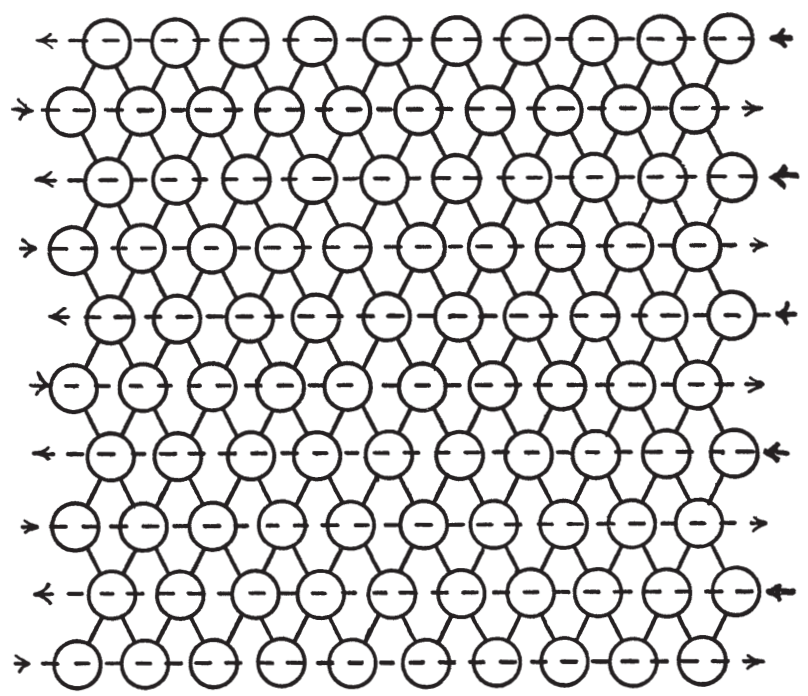

løber den største smidighed langs armene, hvilket også gør det lettere at bevæge skuldrene og bøje albuerne (fig. 1). Hvis man kun har albuelange ærmer, kan man lade dem være løse, men hvis man har hellange ærmer, skal de bindes på plads over albuen ligesom et par gammeldags ærmestrammere. Er der luffer i ærmerne, bindes de på plads om håndleddet for at hindre, at de glider af, eller at ærmet klumper sig sammen om håndroden og tommelfingeren, hvilket $\mathrm{i}$ kamp kunne få katastrofale følger. ${ }^{18}$

Tråden, ringene er lavet af, kan fremstilles på flere måder. Man kan begynde med smalle jernbarrer eller med at klippe jernplade i strimler og så trække disse til tynd tråd gennem mindre og mindre huller i en sænke. Trådens tværsnit afhænger af sænkens udformning, og sænken giver individuelle, genkendelige trækmærker på tråden i hele dens længde og i dens tværsnit. ${ }^{19}$

Alternativt kan man smede tråden, enten ud fra en ubearbejdet jernluppe eller fra afklippede strimler af jernplade. Denne metode giver tråd med kvadratisk eller rektangulær tværsnit og andre lige så let genkendelige mærker på hele trådens længde. ${ }^{20}$

Når tråden er fremstillet, skal den vindes op, så den kan viderebearbejdes til ringe. Det er sandsynligvis blevet gjort over en rulle med en passende diameter, men ingen ruller er hverken afbildet, bevaret eller fundet arkæologisk, så det må betegnes som et kvalificeret eksperimentel arkæologisk bud med etnografisk støtte, afledt af et praktisk problem. Den oprullede tråd klippes i passende stykker, der viderebearbejdes til halvfærdige ringe. Resultatet er, at mange ringe nærmest er ovale frem for cirkulære og derfor sidder mere stabilt 


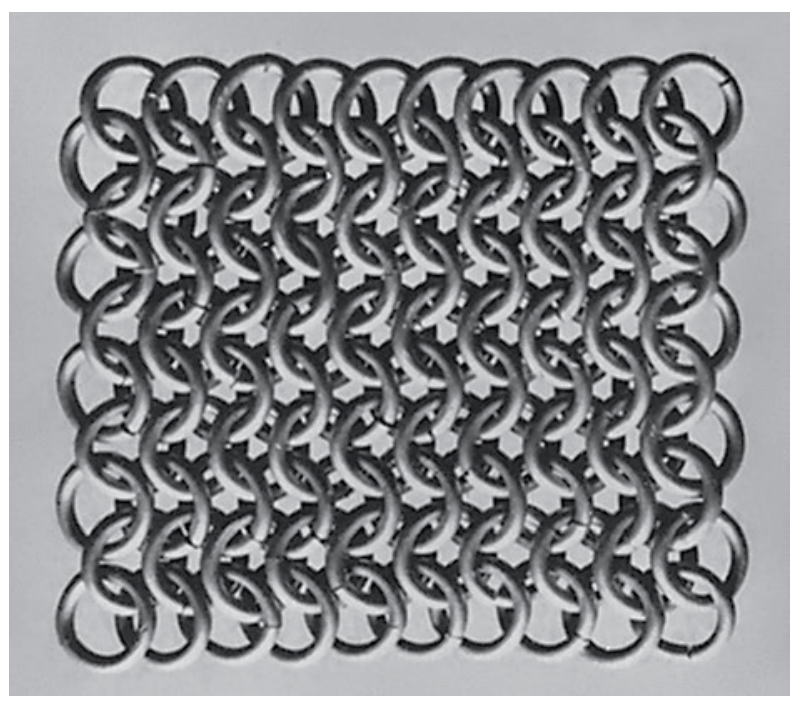

Fig. 4. "Domino"-

banerne som de fremtræder i forbindelse med fremstilling af ringbrynje af, som her, knebne ringe efter opskriften på fig. 3 . - Efter Burgess 1953b. Cambridge University Press.

The "domino" rows as they appear in connection with the production of ring mail of, as here, butted rings according to the procedure in figure 3 .

i det færdige stykke ringbrynje. De halvfærdige jernringe lukkes enten enkeltvis ved essesvejsning eller udstyres med nittehuller til senere samling, eller knibes blot sammen med en tang. ${ }^{21}$

Alternativt til de essesvejsede ringe kan man stanse ringe ud af en jernplade og derefter slibe dem til. Udstansede ringe er let genkendelige, når en ringbrynjegenstand undersøges, fordi slaggemønsteret løber på tværs af ringene i stedet for rundt på ringene, som tilfældet er på ringe lavet af trukket eller smedet tråd. Den ovennævnte hauberk fra Hedegård fra romersk jernalder er lavet af halvt udstansede ringe og halvt nittede. Metoden med udstansede ringe ses ikke brugt i stykker af ringbrynje fra Romerriget og heller ikke i middelalderlige ringbrynjegenstande. ${ }^{22}$

Så samles ringene med fire lukkede forbundet med én åben, der straks nittes sammen, og arbejdet fortsættes ved at forbinde disse kvintetter med flere åbne ringe. Det betyder, at i en hvilken som helst rustningsdel lavet af ringbrynje kan maksimalt halvdelen af ringene være lukkede, resten skal være nittet eller knebet sammen. Da designet og konstruktionen af rustningsdele af ringbrynje blev mere og mere sofistikeret i løbet af 1300-tallet, opgav man de lukkede ringe og brugte alene nittede ringe. Til sidst, i løbet af 1600- og 1700-tallet, da rustningsdele af ringbrynje helt mistede sin funktion som kropsbeskyttelse, nøjedes man med at knibe ringene sammen. Derfor er konstruktionsmetoden en af de vigtigste indikatorer, når man skal datere løsfundne stykker af ringbrynje. $^{23}$ 


\section{Ringbrynje fra Aarhus}

Fra Aarhus kendes fem ringbrynjestykker, som er fundet inden for de sidste godt 100 år. De tre er løsfund indleveret til det tidligere Aarhus Museum, hvis byhistoriske samlinger i dag befinder sig i købstadsmuseet Den Gamle By, og de sidste to små stykker er fundet under udgravning på Bispetorvet lige syd for Domkirken og opbevares på Moesgård Museum.

Stykkerne fra Bispetorvet er små, irregulære stykker i dårlig bevaringsstand. ${ }^{24}$ Det største stykke, der er det bedst bevarede, måler ca. 5x3,5 cm. Det er lavet af jernringe med en diameter på ca. $8,5 \mathrm{~mm}$ og tre messingringe med en diameter på ca. $7 \mathrm{~mm}$ siddende i, hvad der originalt må have været en under- eller overkant (fig. 5). Da det blev udgravet, var det blot et fladt, rektangulært, ukarakteristisk stykke forrustet jern med en besynderlig ujævn overflade og med de tre messingringe lige synlige i kanten. Ved afrensning kom strukturen af ringene frem, og det kunne identificeres som et stykke ringbrynje. Stykkerne er så forvitret, at det ikke engang er muligt at afgøre, hvordan jernringene er lavet, endsige hvad de engang har været en del af. Til gengæld kan stykkerne dateres stratigrafisk, idet de er fundet i jordfylden i et grubehus, som kan dateres til slutningen af 900-årene, og de føjer sig derved til den fine danske samling af før- eller tidligmiddelalderlige ringbrynjefund.

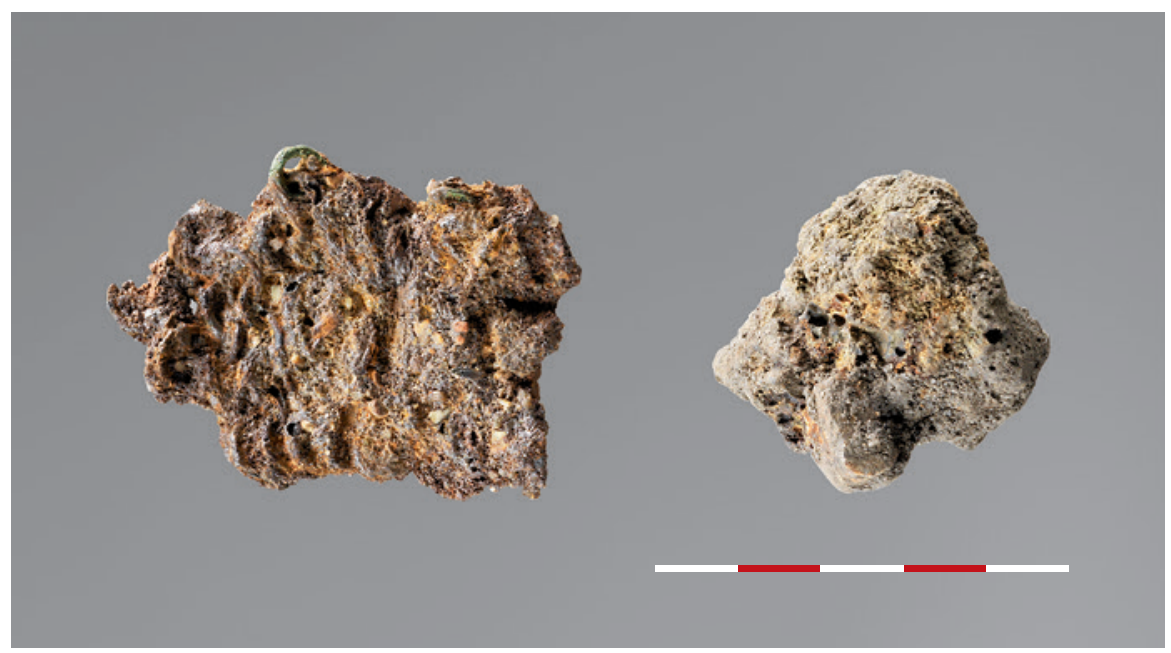

Fig. 5. Ringbrynjestykkerne fra Bispetorvet i afrenset tilstand. De er så forvitret, at ringene smuldrer. - Fotoafdelingen, Moesgård.

The pieces of ring mail from Bispetorv after cleaning. They are so degraded that the rings are disintegrating. 


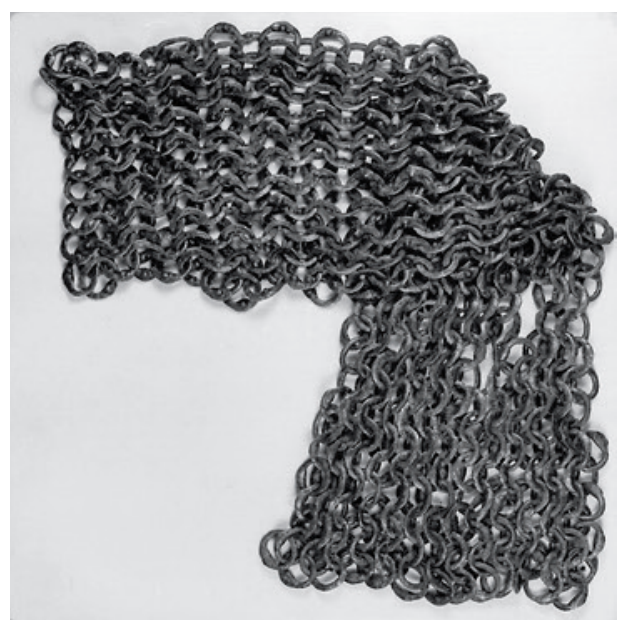

Fig. 6. Ringbrynjestykke fundet på grunden til Graven 21. Den største smidighed er på den smalle led, så det er sandsynligvis et dække for en armhule eller lignende. - Den Gamle By, Danmarks Købstadsmuseum.

A piece of ring mail found at the site of 21 Graven. Its greatest flexibility is across its width, so it probably covered an armpit or similar.

Et aflangt stykke ringbrynje er fundet på grunden til Graven 21 og indleveret til Aarhus Museum i 1944 (fig. 6). ${ }^{25}$ Det er et stykke på ca. 26x7 cm med den største smidighed på den smalle led. Stykket kan tolkes som et dække for en armhule eller et andet sårbart sted, hvor to plader fra en pladerustning har stødt sammen. Det har været syet fast på en underklædning, så det var til at holde på plads. Det er nok det formål, langt de fleste ikke-iturevne småstykker af ringbrynje, vi finder i høj- og senmiddelalderlige sammenhænge, har haft.

Et brigantineærme af ringbrynje er fundet et sted i Aarhus og indleveret til Aarhus Museum (fig. 7). ${ }^{26}$ Det er ca. 49 cm langt, en ganske pæn ærmelængde, og har en åbningsstørrelse på ca. $25 \mathrm{~cm}$ ved håndleddet, hvilket ikke er særligt stort, når man tænker på, at der skal have været plads til både underklædning og tøj mellem ringbrynjeærmet og huden. For at gøre det lettere at få det snævre ærme af og på er det slidset ca. $6 \mathrm{~cm}$ op ved håndleddet. Det er et vellavet ærme med den største smidighed på langs og en ca. $10 \mathrm{~cm}$ stor trekantet udtagning til albuen, så ærmet både sidder bedre på armen, og det er nemmere at bevæge sig. Det har ikke kunnet nå længere end trefjerdedele op ad overarmen, så der er plads til et pufærme på underklædningen, ganske som doubleten har det i slutningen af 1500-tallet. Andre løse ringbrynjeærmer fundet i Danmark når helt op til skulderen. De har endda ekstra flapper i ærmernes overkant til at beskytte selve skulderen, armhulen og lidt af ryg og brystkasse, hvilket kunne tyde på, at de er ældre end ærmet fra Aarhus. ${ }^{27}$

Det sidste stykke ringbrynje i Den Gamle Bys gemmer er en krave fra grunden til Volden 27 og indleveret i 1907 (fig. 8). ${ }^{28}$ Kraven blev fundet i to stykker og med underkanten flænset op. Den er senere blevet sat nænsomt og troværdigt 


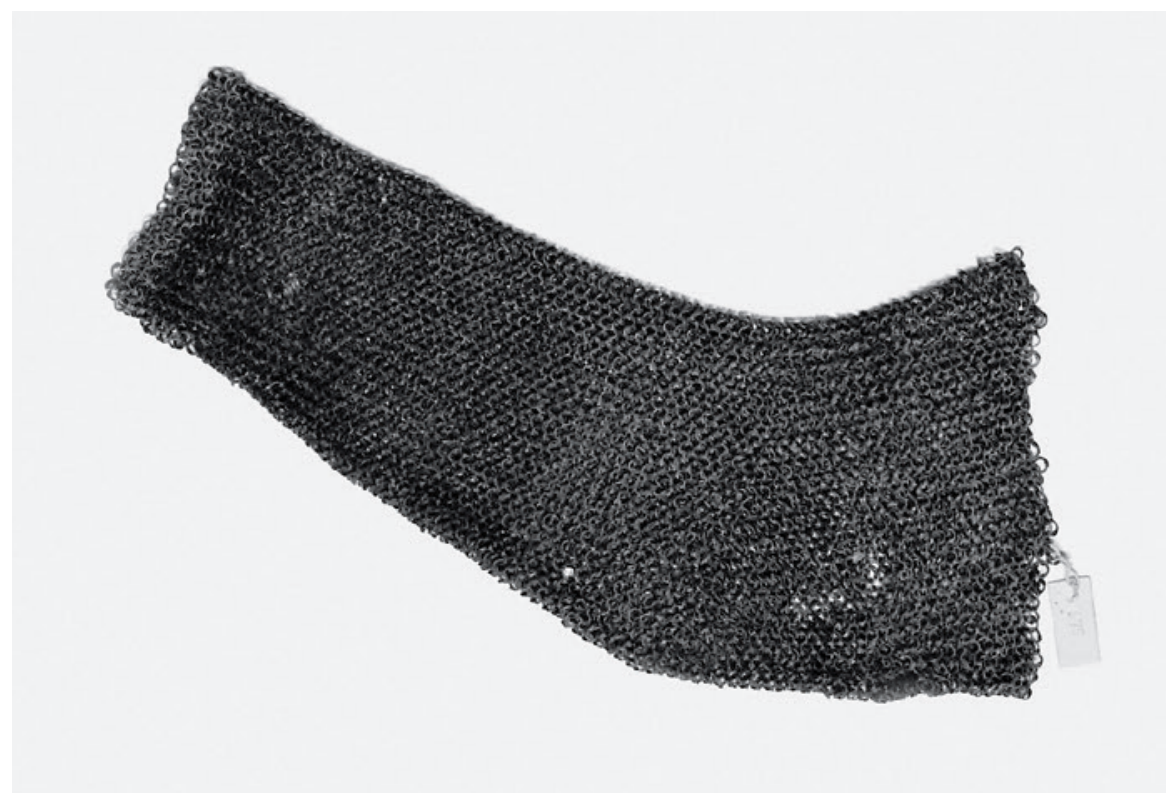

Fig. 7. Brigantineærme fundet et sted i Aarhus. Ærmet skulle bruges på samme måde, som det ses på fig. 2, dog er det ca. 100 år yngre og kortere, og der er plads til et pufærme over det, ganske som tøjmoden foreskriver. - Den Gamle By, Danmarks Købstadsmuseum.

A brigandine sleeve found somewhere in Aarhus. The sleeve was intended to be used in the same way as shown in figure 2. However, it is c. 100 years later and also shorter there so is room for a puff sleeve over it, exactly as prescribed by the fashion of the time.

sammen igen under konservering og fremstår i dag næsten lige så imponerende, som den må have gjort som ny. Den har en halsvidde på ca. $50 \mathrm{~cm}$, og den er ca. $16 \mathrm{~cm}$ bred på et af de få steder, hvor den fulde bredde kan måles. Kraven er et kvalitetsprodukt. Om selve metallet også er af høj kvalitet, kan ikke afgøres uden metallurgiske analyser, men der er gjort meget ud af fremstillingen. Kraven har en enkelt række af messingringe i overkanten og tre rækker i underkanten for udseendets skyld. Denne krave har helt klart skullet vises frem.

Halskanten er $4 \mathrm{~cm}$ bred og lavet af kraftigere og mindre ringe end resten af kraven. Det giver bedre hold på kanten, den er tættere og dermed mere sikker, og kraven vil sidde bedre og pænere om halsen på en bærer. Under halskanten er vævningen af kraven meget løsere. Den har indtagninger og udtagninger midt for, så den får en trekantet udformning i underkanten. Ud over at sørge for, at kraven ligger pænere på den øverste del af brystkassen, skaber ud- og indtagningerne også visuelle effekter med de forskellige lysreflekser, ringene giver, når de ligger i forskellige retninger. Tråden er tyndere end i 
halskanten, og nitteområderne på ringene er hamret eller trykket meget flade. Nitterne er meget ens over hele kraven, og de er velslåede.

Løse kraver af ringbrynje kendes fra 1300-tallet, men pragtkraver som denne ses fra midten af 1500-tallet og århundredet ud. De ses mest i det nuværende Tyskland og forbindes som regel med landsknægte og deres helt specielle tøjstil. Denne slags kraver kendes bedst som små ponchoer uden lukning med en lille standkrave, på engelsk en "Bishop's Mantel", fordi de ligner en miniature messehagel. ${ }^{29}$ De er som regel kun lavet af jernringe i det enkleste mulige design. En så luksuriøs og pyntet udgave som kraven fra Volden 27 ses sjældent.

Som et lille kuriosum kan det i øvrigt afslutningsvis nævnes, at ringbrynje skam ikke helt er gået af brug. Den har fået en veritabel renæssance hos slagtere samt dyrepassere og havbiologer, der dykker med hajer og andre rovfisk. Ringbrynjes smidighed og sejhed har i nutiden reddet mange lemmer fra bid og snitsår, ganske som det i fortiden har reddet mange lemmer fra grimme hugsår.

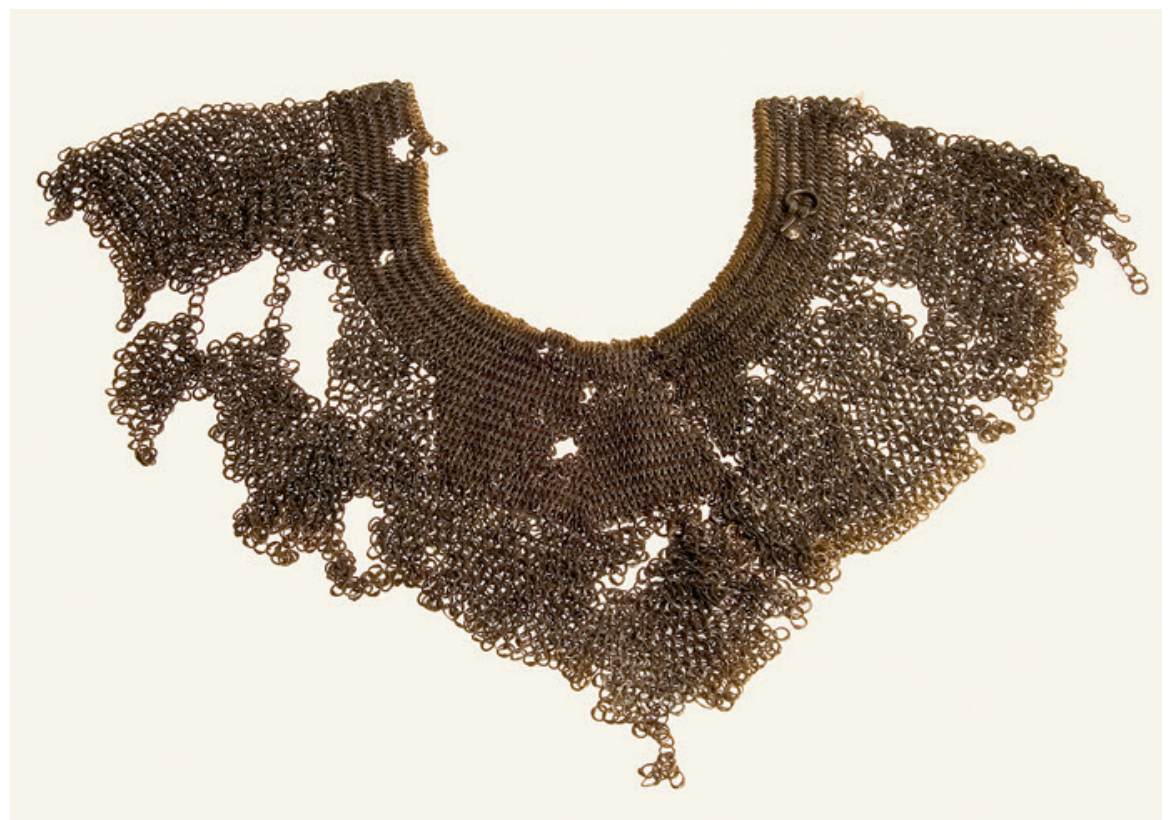

Fig. 8. Ringbrynjekrave fundet på grunden til Volden 27. Man kan se, hvor velmodelleret kraven er, og rækkerne af messingringe skinner tydeligt. Denne krave skulle ses. - Den Gamle By, Danmarks Købstadsmuseum.

Ring mail collar found at the site of 27 Volden. It is clear how well-modelled the collar is, and the rows of brass rings clearly shine. This was a collar clearly intended to be seen. 


\section{NOTER}

1. Hawkins 1997, s. 12-13. På engelsk betyder "mail" også "brevpost" og får derfor ofte et forled til enten "ring mail" eller "chain mail" for at undgå misforståelser.

2. Bishop \& Coulston 2006, s. 63; Jensen 2003, note 35 til kap. 2.

3. Robinson 1975, s. 164.

4. HOM 151x1054, ASR C 3281, NM 19503, NM C 13527, Jouttijärvi 1996.

5. Madsen 1997, s. 85; Jouttijärvi 1996, s. 58.

6. Bishop \& Coulston 2006, s. 271.

7. Blair 1972, s. 23f. ; Pfaffenbichler 1992, s. 4; Arkell 1956, s. 83. Hauberken fra Hedegård er en sådan romersk variant, også selv om den er fra det nuværende tyske eller polske område, Madsen 1997, s. 85.

8. Dette kendes bedst fra Bayeux Tapetet, og ses på de højstrangerende personer som Hertug/Kong Vilhelm, Biskop Odo og deres generaler. Se f.eks. Rud 2008, s. 121.

9. Blair 1972, s. 27, 29 og Ill. 13; Norman 1972, Ill. 16.

10. Pind 2009, s. 49; Pfaffenbichler 1992, s. 62; Blair 1972, kap. 2-5.

11. Blair 1972, s. 144.

12. Måske blev brigantinen allerede brugt i 1300-tallet, hvorved en enkelt er bevaret efter Valdemar Atterdags indtagelse af Gotland i 1361, smidt i en af massegravene lavet kort efter slaget ved Visby d. 27. juli, kendt som Korsbetningen, og udgravet i løbet af de første tre årtier af 1900-tallet. Pind 2009, s. 65.

13. Blair 1972, s. 58, 118; Köhler 1963, s. 223-224.

14. Pind 2009, s. 67-79.

15. Pind 2009, s. 43-49.

16. Arkell 1956, s. 83.

17. Arkell 1956, s. 84; Hawkins 1997, s. 12.

18. Blair 1972, s. 29.

19. Burgess 1953a, s. 49; Smith 1959, s. 65.

20. Jouttijärvi 1996, s. 56.

21. Burgess 1953a, s. 49-50; Smith 1959, s. 60; Arkell 1956, Pl. XIa; Jouttijärvi 1996, s. 54.

22. Jouttijärvi 1996, s. 54-55, fig. 3a og 3b; Bishop \& Coulston 2006, s. 241-242; Smith 1959, s. 60.

23. Arkell 1956, s. 83; Burgess 1953a, s. 50; Blair 1972, s. 20.

24. FHM 5124 X1430 og X1463. X1463 er det største stykke.

25. DGB 00314:44.

26. DGB 00675.

27. NM D346/1964.

28. DGB 00984.

29. Blair 1972, tekst til Ill. 38; Dufty 1968, Pl. CXXVIIe.

\section{LITTERATUR}

Arkell, A.J. 1956: The Making of Mail at Omdurman. Kush 4, s. 83-84.

Bishop, M.C. \& J.C.N. Coulston 2006: Roman Military Equipment: From the Punic Wars to the Fall of Rome. Oxford, 2. udg.

Blair, C. 1972: European Armour. London, 2. udg. 
Burgess, E.M. 1953a: The Mail-maker's Technique. The Antiquaries Journal XXXIII, 1-2, s. $48-55$.

Burgess, E.M. 1953b: Further Research into the Construction of Mail Garments. The Antiquaries Journal XXXIII, 3-4, s. 193-202.

Dufty, A.R. 1968: European Armour. London.

Hawkins, Q. 1997: Hand-locked Iron. Medieval Life 6, s. 11-14.

Jensen, J. 2003: Danmarks Oldtid. Aldre Jernalder 500 f.Kr. til 400 e.Kr. København.

Jouttijärvi, A. 1996: Fremstilling af ringbrynjer. I: H. Lyngstrøm (red): Early iron, Netvark for tidlig jernteknologi 1, s. 53-60.

Köhler, C. 1963: A History of Costume. New York.

Madsen, O. 1997: Hedegård - a rich village and cemetery complex of the Early Iron Age on the Skjern River. Journal of Danish Archaeology 13, s. 57-93.

Norman, V. 1972: Arms and Armour. London, 2. udg.

Pfaffenbichler, M. 1992: Armourers. London.

Pind, L.H. 2009: Rustningen: til hest \& til fods. Upubliceret speciale, Aarhus Universitet, Afdeling for Antropologi, Arkæologi og Lingvistik, Afdeling for Middelalder- og Renæssancearkæologi.

Robinson, H.R. 1975: The Armour of Imperial Rome. London.

Rud, M. 2008: Bayeux Tapetet og slaget ved Hastings 1066. København.

Smith, C.S. 1959: Methods of Making Chain Mail (14 $4^{\text {th }}$ to $18^{\text {th }}$ Centuries): A Metallographic Note. Technology and Culture 1, 1, s. 60-67. 


\section{Ring mail from Aarhus}

During the almost two millennia which elapsed from the introduction of ring mail into Europe via the Roman army in the 3rd century BC until body armour went out of general use in the course of the 17th century, ring mail has played a surprisingly major role, despite the weakness of its presence in the archaeological record. When the Roman Empire collapsed in the 5th century $\mathrm{AD}$, ring mail became the dominant form of armour for almost a millennium. The most commonly occurring piece, the hauberk (fig. 1), appeared with a range of variations from the Roman Empire until long after the general use of armour ceased. The introduction of plate armour in the 14th century led to flexible ring mail developing from general to more specialised use: to protect the parts of the body and joints which non-flexible iron plates were unable to cover and as a supplement to cheap types of armour such as the brigandine (fig. 2). When armour technology had, in general, reached the limit of its usefulness in the 17 th century, and in step with a decline in the art of making ring mail apparent through the centuries, this form of armour largely went out of use in Europe. In the Middle East and in Africa it acquired a more ceremonial role, as a status symbol for powerful chieftains, and with no real link to its origin as body armour.

Even though the construction of ring mail is easy to explain - four rings are joined together with a fifth and these quintets are then linked together with further rings (fig. 3) - the practical execution of the technique is rather more difficult as, when the rings are correctly assembled, ring mail is only flexible in one direction (fig. 4). As the rings themselves can be made in several different ways - from wire hammered out from ingots or as cut strips of sheet iron or perhaps drawn through a swage or stamped out whole from sheet iron - and they can be assembled in various ways - either riveted, forge-welded or just butted together this gives many possible permutations for the construction of ring mail. These factors make a useful contribution when determining the type and date of archaeological finds of ring mail.

There are five archaeological records of ring mail from Aarhus. The major excavation in Bispetorv yielded two small pieces (fig. 5). These are dated stratigraphically to the 10th century, but they are too small for their original function to be ascertained. The example from 21 Graven (fig. 6) is a long, narrow piece which was probably used to cover an armpit or similar in association with plate armour, but it is not possible to give this a more precise date than the High or Late Middle Ages. Other finds from Aarhus include a brigandine sleeve (fig. 7), dated to the end of the 16th century on the basis of its appearance and construction. The example from 27 Volden (fig. 8) is a well-made ring mail collar, dated to the second half of the 16th century on the basis of European parallels and the quality of its craftsmanship.

Ring mail has not, however, completely disappeared. It has enjoyed a veritable renaissance in recent times with butchers, zoo keepers and marine biologists who dive with sharks and other piscine predators. Ring mail's flexibility and toughness has saved many limbs from bites and cuts in modern times, just as it shielded many limbs from ugly wounds in the past.

Lea Hillebrenner Pind Moesgård Museum 